\title{
DIAZEPAM AS AN ADJUVANT AGENT IN REGIONAL ANAESTHESIA
}

\author{
Hentr Drolet, M.D. and Michel Botsvert, M.D. ${ }^{\circ}$
}

The SEDATIVE, ANXIOLYTIC AND MUSCLE-hELAXANT PROPERTIES of injectable diazepam (Valium Roche) have been the subject of numerous publications. Its use in association with general anaesthesia as premedication, and as an induction agent, has been reported, usually with favour, by Baker ${ }^{1}$, Dobkin ${ }^{2}$, Wyant ${ }^{3}$ and Eisenberg ${ }^{4}$. Emmett ${ }^{5}$ has reported favourably on its use in conjunction with topical anaesthesia in endoscopic procedures, and McTigue obtained good results with diazepam as an adjuvant in ophthalmological operations.

The last two papers were of particular interest to us, since one of the problems with regional anaesthesia is lack of patient acceptance of the concept of remaining conscious during operation. We find this to hold particularly true, in our patient population, in the case of epidural anaesthesia, a procedure of particular interest to us. An agent with the potential of reducing patient resistance to this procedure seemed to us to be of great benefit, and such an agent should be able, ideally, to isolate the patient affectively from the stresses of the surgical environment. From the reports just cited, and from the known pharmacological properties of diazepam, we felt that its use as an adjunct in epidural anaesthesia merited study.

\section{Material and Methods}

One hundred and ninety-two patients were assigned according to a randomized schedule to one of four groups differing from each other in the medication they received before and during surgical operations. All groups received the same hypnotic on the evening before the operation, and all groups received atropine 0.4 mgm one hour before the operation. In addition, Group I received only meperidine; Group II, meperidine and diazepam; Group III only diazepam; and Group IV, also only diazepam, but according to a different time schedule. The complete dosage schedule is given in Table I.

Patients admitted to the study were adults of both sexes ( $16-80$ years). Only patients undergoing surgery below the level of the umbilicus were considered as candidates for the study, and they had to qualify as good anaesthetic risks. Reasons for exclusion from the study were: a grade of 3,4 , or 5 on the anaesthetic risk scale of the American Society of Anesthesiologists; concomitant severe pulmonary disease, blood dyscrasia, renal or hepatic disease; current treatment with alpha- or beta-adrenergic blocking agents; a proposed surgical operation of too short a duration of time, as well as surgery related to obstetrics (delivery, curettage, Caesarean).

The description of the patients is given in Table II, and the list of operations to which the members of the four groups were submitted is given in Table III.

-Department of Anaesthesia, Hôpital St-Ambroise de Loretteville, P.Q.

Canad. Anaesth. Soc. J., vol. 19, no. 3, May 1972 
TABLE I

Dosage Schedule

\begin{tabular}{|c|c|c|c|c|}
\hline \multirow{2}{*}{$\begin{array}{l}\text { Time of } \\
\text { Administration }\end{array}$} & \multicolumn{4}{|c|}{ Groups } \\
\hline & I & II & III & IV \\
\hline $\begin{array}{l}\text { Evening before } \\
\text { the operation }\end{array}$ & $\begin{array}{l}\text { methyprylon } \\
300 \mathrm{mg}\end{array}$ & $\begin{array}{l}\text { methyprylon } \\
300 \mathrm{mg}\end{array}$ & $\begin{array}{l}\text { methyprylon } \\
300 \mathrm{mg}\end{array}$ & $\begin{array}{l}\text { methyprylon } \\
300 \mathrm{mg}\end{array}$ \\
\hline $\begin{array}{l}\text { One hour } \\
\text { pre-op }\end{array}$ & $\begin{array}{l}\text { meperidine } \\
70 \mathrm{mg} \text { (average) } \\
+ \text { atropine } \\
\text { gr. } 1 / 150\end{array}$ & $\begin{array}{l}\text { meperidine } \\
70 \mathrm{mg} \text { (average) } \\
+ \text { atropine } \\
\mathrm{gr} 1 / 150\end{array}$ & $\begin{array}{l}\text { diazepam } \\
5 \text { mg, i.v. } \\
+ \text { atropine } \\
\text { gr } 1 / 150\end{array}$ & $\begin{array}{l}\text { atroping } \\
\text { gr } 1 / 150\end{array}$ \\
\hline $\begin{array}{l}\text { Immediately } \\
\text { preceding the } \\
\text { epidural injection }\end{array}$ & $\begin{array}{l}\text { meperidine } \\
50 \text { mig }\end{array}$ & $\begin{array}{l}\text { diazepam } \\
10 \mathrm{mg} \text { i.v. }\end{array}$ & $\begin{array}{l}\text { diazepam } \\
10 \mathrm{mg} \text { i.v. }\end{array}$ & $\begin{array}{l}\text { diazepam } \\
10 \mathrm{mg} \text { i.y. }\end{array}$ \\
\hline $\begin{array}{l}\text { At initiation of operation, } \\
\text { j.e. } 20-30 \text { minutes after } \\
\text { the epidural injection }\end{array}$ & nil & nil & nil & $\begin{array}{l}\text { diazeparn } \\
10 \mathrm{mg} \text { i.v. }\end{array}$ \\
\hline
\end{tabular}

TABLE II

Patient Description

\begin{tabular}{|c|c|c|c|c|c|c|c|c|c|}
\hline \multirow[b]{2}{*}{ Group } & \multicolumn{3}{|c|}{ Number of Patients } & \multicolumn{2}{|c|}{ Age (Years) } & \multicolumn{2}{|c|}{ Height (Inches) } & \multicolumn{2}{|c|}{ Weight (Pounds) } \\
\hline & Male & Female & Total & Mean & Range & Mean & Range & Mean & Range \\
\hline $\begin{array}{l}\text { I } \\
\text { II } \\
\text { IIV }\end{array}$ & $\begin{array}{l}26 \\
18 \\
19 \\
22\end{array}$ & $\begin{array}{l}23 \\
30 \\
30 \\
24\end{array}$ & $\begin{array}{l}49 \\
48 \\
49 \\
46\end{array}$ & $\begin{array}{l}44 \\
41 \\
42 \\
38\end{array}$ & $\begin{array}{l}19-71 \\
17-75 \\
21-80 \\
16-70\end{array}$ & $\begin{array}{l}64 \\
64 \\
60 \\
64\end{array}$ & $\begin{array}{l}59-75 \\
60-72 \\
60-73 \\
59-70\end{array}$ & $\begin{array}{l}146 \\
146 \\
146 \\
144\end{array}$ & $\begin{array}{l}71-210 \\
88-210 \\
92-205 \\
95-213\end{array}$ \\
\hline $\begin{array}{l}\text { Combined } \\
\text { Data }\end{array}$ & 84 & 107 & 192 & 41 & $16-80$ & 63 & $59-75$ & 145. & $71-213$ \\
\hline
\end{tabular}

TABLE III

Surgtcal Distribution

\begin{tabular}{lrrrrrr}
\hline & \multicolumn{5}{c}{ Groups } \\
\cline { 2 - 5 } \multicolumn{1}{c}{$\begin{array}{c}\text { Type of } \\
\text { Operation }\end{array}$} & I & II & III & IV & Total \\
\hline Herniorrhaphy & 14 & 5 & 11 & 3 & 33 \\
Hysterectomy & 7 & 6 & 12 & 19 & 34 \\
Saphenectomy & 1 & 4 & 1 & 5 & 11 \\
Cystoscopy & 3 & 2 & 3 & 3 & 11 \\
Excision of cyst & 2 & 5 & 1 & 4 & 12 \\
Reduction of iracture & 1 & 3 & 1 & 1 & 6 \\
Hemorrhoidectomy & 2 & 9 & 10 & 8 & 29 \\
Stripping & 2 & 2 & 1 & 1 & 6 \\
Meniscectorny & - & 1 & 2 & 2 & 5 \\
Colpotomy & -17 & 1 & 1 & 2 & 4 \\
Miscellaneous & 17 & 10 & 6 & 8 & 41 \\
Total & 49 & 48 & 49 & 46 & 192 \\
\hline
\end{tabular}

The anaesthetic procedure was the same for all patients, and was administered by one of the two authors. It consisted of a single epidural injection of a mixture of equal parts of 2 per cent mepivacaine (Carbocaine) without epinephrine and 2 per cent lidocaine (Xylocaine with $1 / 200,000$ epinephrine A 21 gauge trocar was used, manufactured according to the specifications of the authors. 
Each patient was evahated at five different stages of the procedure: on entrance to the operating suite, immediately after the epidural injection, at the beginning of the surgery, 30 minutes later, and in the Recovery Room. Each patient was also seen on the day after the operation to establish the extent to which he could recall the procedure. At each stage measurements were made of pulse, systolic and diastolic blood pressure (by sphygmomanometer), and respiratory rate. Each patient was also rated on a five-point scale (see Table IV), for a series of eight behavioural factors: co-operation, relaxation, euphoria, agitation, anxiety, depression, confusion, and slurred speech. Side effects were watched for.

All findings were recorded on individual patient evaluation record sheets, and were submitted to an Analysis of Variance.

TABLE IV

\begin{tabular}{|c|c|c|c|c|c|}
\hline & \multicolumn{5}{|c|}{ Rating Scale } \\
\hline & 0 & 1 & 2 & 3 & 4 \\
\hline $\begin{array}{l}\text { Co-operation } \\
\text { Relaxation }\end{array}$ & None & Slight & Fair & Good & Complete \\
\hline Euphoria & $"$ & $"$ & $"$ & $"$ & "' \\
\hline $\begin{array}{l}\text { Agitation } \\
\text { Anxiety }\end{array}$ & $\begin{array}{l}\text { Severe } \\
\text { "I }\end{array}$ & $\underset{11}{\text { Marked }}$ & Moderate & Mild & None \\
\hline Depression & $"$ & $n$ & " & $"$ & $"$ \\
\hline Confusion & t & "' & $"$ & $"$, & $"$ \\
\hline Slurred Speech & $"$ & $" 2$ & $"$ & tt & $"$ \\
\hline
\end{tabular}

\section{Results}

Vital Signs

Only the pulse rate varied in a statistically significant fashion between the groups, at the time of entrance to the operating suite, during the operation and in the Recovery Room (Table V), but clinically these differences were unimportant. Pulse rate and the other vital signs (blood pressure and respiratory rate) remained stable within each group throughout the time-course of the experiment.

\section{Behavioural Factors}

The observations made on the behavioural factors are more interesting. Statistical differences between groups are recorded in Table V. The importance of these differences is less obvious clinically. The groups were essentially similar with respect to six of the parameters. They all showed a reasonable amount of anxiety on entering the operating suite, a moderate degree of co-operation, not much confusion, agitation or depression, and slurred speech was not particularly noticeable. With respect to relaxation and euphoria, although neither was present to a large degree in any of the groups on entrance to the operating suite, the groups did differ, and in the same order for both factors. Thus Group III had the highest mean scores for both relaxation and euphoria (1.59 and 1.24 , respectively), whereas Group IV had the lowest $(0.52$ and 0.17$)$. The mean scores for Group I were 1.33 and 1.02; for Group II, 1,25 and 0.83 .

Comments may also be made on the changes in the behavioural factors recorded throughout the experiment. Statistically significant differences from the mean of 
TABLE $V$

Statisfically Significant Differences Between groups

\begin{tabular}{|c|c|c|c|c|c|}
\hline & Entrance & $\begin{array}{c}\text { After } \\
\text { Epidural }\end{array}$ & Intervention & $\begin{array}{l}30 \text { Minutes } \\
\text { Later }\end{array}$ & $\begin{array}{c}\text { Recovery } \\
\text { Room }\end{array}$ \\
\hline \multicolumn{6}{|c|}{ Vital Signs } \\
\hline Pulse Rate & $\begin{array}{l}1 V^{*} \\
\text { (lowest) }\end{array}$ & - & - & $\begin{array}{l}\text { IV* } \\
\text { (lowest) }\end{array}$ & $\begin{array}{l}\text { IVt } \\
\text { (lowest) }\end{array}$ \\
\hline $\begin{array}{l}\text { Systolic } \\
\text { Pressure }\end{array}$ & - & $\begin{array}{l}\text { IV* } \\
\text { (lowest) }\end{array}$ & - & - & - \\
\hline $\begin{array}{l}\text { Diastolic } \\
\text { Pressure }\end{array}$ & - & 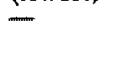 & - & - & - \\
\hline $\begin{array}{l}\text { Respiratory } \\
\text { Rate }\end{array}$ & - & - & - & - & - \\
\hline \multicolumn{6}{|c|}{ Behavioural Factors } \\
\hline Co-operation & 二 & - & - & - & - \\
\hline Relaxation & $\begin{array}{l}11 * * \\
(\operatorname{less})\end{array}$ & $\begin{array}{l}\text { IV** } \\
\text { (less) }\end{array}$ & - & - & 一 \\
\hline Euphoria & $\begin{array}{l}\text { IV** } \\
\text { (less) }\end{array}$ & $\begin{array}{l}\text { III }{ }^{* *} \\
\text { (more) }\end{array}$ & - & - & - \\
\hline Agitation & $\begin{array}{l}\text { III** } \\
\text { (less) }\end{array}$ & - & - & - & $\longrightarrow$ \\
\hline Anxiety & $\begin{array}{l}\text { III* } \\
\text { (less) }\end{array}$ & $\begin{array}{l}\text { I11* } \\
\text { (less) }\end{array}$ & $\begin{array}{l}\text { III* } \\
\text { (less) }\end{array}$ & - & - \\
\hline Depression & & $\bar{T}_{x} x=$ & - & - & 一 \\
\hline Confusion & $\begin{array}{l}\mathrm{III}^{*} \\
\text { (more) }\end{array}$ & $\begin{array}{l}\mathrm{I}, \mathrm{IV}^{* *} \\
\text { (less) }\end{array}$ & $\operatorname{mmnt}$ & - & - \\
\hline Slurred Speech & $\begin{array}{l}\text { IV" } \\
\text { (less) }\end{array}$ & $\begin{array}{l}\text { II, III*** } \\
\text { (more) }\end{array}$ & - & - & $\begin{array}{l}\text { II I }{ }^{* *} \\
\text { (less) }\end{array}$ \\
\hline
\end{tabular}

$\bullet p=0.05$.

$t_{\mathrm{p}}=0.01$. Analysis of Variance.

the patient scores are recorded for each group in Table VI. Again, however, the clinical conclusions are the more interesting. With respect to four factors, little change was noted: co-operation remained at the same level throughout (moderate); agitation, depression and slurred speech, not marked in any group, remained at the same low level throughout.

Changes were noted however in the other factors. Anxiety diminished markedly (from a range for the four groups at the beginning, of 2.14-2.98 to a range, at the end of the experiment, in the Recovery Room, of 3.85-3.95). Relaxation improved (from 0.52-1.59 to 2.83-3.00), and euphoria increased (from 0.17-1.24 to 2.59-2.69). Confusion, which was not marked at the time of entrance into the operating suite (3.43-3.89), increased at the time of the epidural injection (2.713.41 ), began to improve thirty minutes after the beginning of surgery $(3.02-3.30)$ and was again not marked in the Recovery Room (3.73-3.92).

Finally, the groups differed considerably in terms of their recall of the procedure on the day after the operation. Group I came close to total recall (mean patient score: 2.37, out of a maximum possible of 3 ), and Group IV had least memory of the procedure (0.98). Groups II and III were more similar to Group IV than to Group I in terms of the degree to which they could recall the procedure ( 1.00 and 1.18 , respectively).

In terms of patient record scores, Group III is superior to the other three groups. Groups I and IV are inferior to Group III, but rather similar to each other, whereas Group II shows the lowest ratings. Clinical impressions are some- 
TABLE Vl

Statistically Significant Changes Wrthin Groups During the Experiment

\begin{tabular}{|c|c|c|c|c|c|}
\hline & Entrance & $\begin{array}{c}\text { After } \\
\text { Epidural }\end{array}$ & Intervention & $\begin{array}{l}30 \text { Minutes } \\
\text { Later }\end{array}$ & $\begin{array}{c}\text { Recovery } \\
\text { Room }\end{array}$ \\
\hline \multicolumn{6}{|c|}{ Vital Signs } \\
\hline $\begin{array}{l}\text { Pulse Rate } \\
\text { Systolic }\end{array}$ & - & - & - & - & - \\
\hline Pressure & - & - & - & - & - \\
\hline $\begin{array}{l}\text { Diastolic } \\
\text { Pressure }\end{array}$ & - & - & - & - & - \\
\hline $\begin{array}{l}\text { Respiratory } \\
\text { Rate }\end{array}$ & - & - & - & - & - \\
\hline \multicolumn{6}{|c|}{ Behavioural Factors } \\
\hline Co-operation & 一 & - & - & - & $\begin{array}{l}\text { I* }^{*} \\
\text { (improved) }\end{array}$ \\
\hline Relaxation & $\begin{array}{l}\text { All groups } \dagger \\
\text { (less) }\end{array}$ & $\begin{array}{l}\text { IV† } \\
\text { (less) }\end{array}$ & - & - & $\begin{array}{l}\text { All groups } \\
\text { (improved) }\end{array}$ \\
\hline Euphoria & $\begin{array}{l}\text { All groups } \dagger \\
\text { (less) }\end{array}$ & $\begin{array}{l}\text { IVt } \\
\text { (less) }\end{array}$ & - & - & $\begin{array}{l}\text { I, li, IVt } \\
\text { (more) }\end{array}$ \\
\hline Agitation & $\begin{array}{l}\text { IV } 1 \\
\text { (more) }\end{array}$ & - & - & - & (less) \\
\hline Anxiety & $\begin{array}{l}\text { All groups } † \\
\text { (more) }\end{array}$ & - & - & - & $\begin{array}{l}\text { I, II, IVt } \\
\text { (less) }\end{array}$ \\
\hline Depression & $\begin{array}{l}\text { II I II, IV } \\
\text { (less) }\end{array}$ & - & - & - & $\begin{array}{l}\text { I, II, IIIt } \\
\text { (less) }\end{array}$ \\
\hline Confusion & $\begin{array}{l}\text { All groupst } \\
\text { (less) }\end{array}$ & $\begin{array}{l}\text { IVt } \\
\text { (less) }\end{array}$ & - & - & $\begin{array}{l}\text { All groupst } \\
\text { (less) }\end{array}$ \\
\hline $\begin{array}{l}\text { Slurred } \\
\text { Speech }\end{array}$ & $\begin{array}{l}\text { I, II, IIIt } \\
\text { (less) }\end{array}$ & $\begin{array}{l}\text { IVt } \\
\text { (less) }\end{array}$ & - & $\begin{array}{l}\text { III } \dagger \\
\text { (less) }\end{array}$ & $\begin{array}{l}\text { All groups } \\
\text { (less) }\end{array}$ \\
\hline
\end{tabular}

what at variance with this ranking, Group III remains the best prepared group, Group IV is the worst, and Groups I and II lie between.

Clinical impressions also yield information concerning the quality of the results achieved which complement the patient record scores. Diazepam was seen to provide a form of psychic relaxation not seen with meperidine, and came closest to providing the clinical result we were seeking. Patients treated with diazepam were more relaxed mentally. Sometimes this was associated with sleep, sometimes by talkativeness during which any subject might be discussed, no matter how diverse or how intimate; rarely, a sudden feeling of sadness might overcome the patient.

The patient treated with diazepam recalled less of the procedure than did those treated with meperidine. Also the quality of the recall differed. Amnesia was generally present for the epidural injection, but not necessarily for the rest of the procedure which, although it usually was not spontaneously remembered, could in fact often be recalled if leading questions were asked. In this sense one might more accurately speak of a "memory gap" than of true amnesia.

The side effects observed were minimal. ${ }^{\circ}$ Several patients were aware of a sud-

-A year before this study began, the authors encountered a case of apnea following the in jection of $10 \mathrm{mg}$ of diazepam intravenously. The apnea was followed by cyanosis, lasted 80 seconds, and necessitated artificial ventilation. No similar occurrence was met with in the present experiment. 
den burning sensation at the site of injection when diazepam was used. No thrombophlebitis ensued in any case in the following days.

\section{Discussion and Conchusions}

Slight, but significant, differences between the four groups were noted, the group (III) treated with diazepam pre-operatively and immediately preceding the epidural injection showing itself to be the best with respect to the observations made on the behavioural factors. Better results would probably have been achieved had larger and more individualized doses been used. The experimental situation however dictated prudence in the use of a new drug, and did not lend itself to drug administration in terms of individual response.

The clinical impressions confirmed the superiority of the treatment used in Group III. In addition, they captured better the qualitative differences between the reactions of the four groups. The tranquilizing properties of diazepam proved to be more satisfactory than the narcotic properties of meperidine in preparing a patient for, and carrying him through, a surgical operation under regional (epidural) anaesthesia. No changes of importance were noted with respect to the vital signs.

The side effects noted, while not severe, are characteristic of intravenous injections of diazepam, and have been noted by other authors ${ }^{1-8}$. The frequency of a burning sensation following intravenous diazepam injection diminishes with the use of larger veins, and by slowing the rate of infusion.

Patient acceptance of diazepam was excellent and its use to a large extent abolished the resistance to the use of epidural anaesthesia usually encountered.

\section{SUMMARY}

A study is described in which 192 patients, randomly assigned to one of four groups, received one of four treatment regimens involving either meperidine or diazepam, or a combination of both, as preparation for surgical operations with epidural anaesthesia. The four regimens are described in detail in the text. Vital signs were measured, and a series of eight behavioural factors were measured at regular stages of the procedure. An Analysis of Variance was performed. Group III, which had received only diazepam, one hour pre-operatively and immediately preceding the epidural injection, was judged the best, both on the basis of the scoring system used for the behavioural factors and of clinical observations. It is our conclusion that the diazepam group was the best prepared for the total procedure, and offered the least resistance to the idea of remaining conscious, by use of epidural anaesthesia, during a surgical operation.

\section{Resume}

La plupart des patients redoutent, à des degrés divers, d’abord d'être anesthésiés par voie vertébrale et ensuite de demeurer conscients en cours d'intervention. Le diazepam est-il un agent susceptible de réduire ou d'annuler cette réticence devant 
un tel type d'anesthésie régionale d'une part, et d'autre part d'opérer un débranchement affectif pendant lopération? C'est l'objet de la présente étude.

Elle comprend 192 patients distribués au hasard en quatre groupes, au niveau de la médication pré-opératoire. Les médicaments utilisés ont été soit le diazepam soit la meperidine, soit une combinaison des deux (les modalités en sont expliquées dans le texte). Ont été mesurés les effets sur les paramètres vitaux et sur le comportement affectif, à différents moments de la procédure. Les résultats ont été analysés statistiquement pour fin de comparaison entre les groupes. Le groupe III, qui ne reçut que du diazepam une heure avant l'opération et juste avant linjection péridurale, s'est avéré le meilleur du point de vue tant physique que psychologique. Nous devons conclure que ce groupe était le mieux préparé pour l'épreuve anesthésique et chirurgicale.

Une fois libérés des cadres rigides du présent travail, les auteurs ont procédé à un assouplissement de lutilisation du diazepam. Des doses "personnalisées" leur ont procuré des résultats absolument remarquables. Jusqu'à ce jour, aucun agent ne leur a donné, de façon sécuritaire, des patients aussi coopératifs et aussi décontractés.

\section{REFERENCES}

1. BAKEF, A.B. Induction of anesthesia with diazepam. Anesthesia, 24: 388 (1969).

2. Dobros, A.B., Israet, J.S., \& Evkrs, W. Double blind evaluation of diazepam for premedication. Can. Anaesth, Soc. J. 17:52 (1970).

3. Wrant, G.M. \& Studney, L.J. A study of diazepam (Valium) for inducation of anaesthesia. Can. Anaesth. Soc. J. 17: 160 (1970).

4. Eisengeng, L. \& KwaN, A.M. Neuroleptanaesthesia with diazepam-morphine in poorrisk surgical patients. Can. Anaesth. Soc. J. 18:465 (1971).

5. EMMETI, J.A.J. The use of intravenous diazepam (Valium) as a sedative and relaxant in urological endoscopic procedures. Can. Anaesth. Soc. J. 17: 242 (1970).

6. McTicue, J.W. \& Unwemer, H.A. The use of diazepam (Valium) in ophthalmic surgery. Tr. Am. Acad, Ophth, and Otol. 73: 78 (1969). 